\title{
Diversity analysis of biocontrol Bacillus isolated from rhizospheric soil of rice-wheat (Oryza sativa-Triticum aestivum L.) at India
}

\author{
Shachi Vardhan ${ }^{1}$, Arvind K Yadav ${ }^{1}$, Akhilesh K Pandey ${ }^{2}$ and Dilip K Arora ${ }^{1}$ \\ The Journal of Antibiotics (2013) 66, 485-490; doi:10.1038/ja.2013.10; published online 22 May 2013
}

Keywords: ARDRA; Bacillus; biocontrol; IGP; scanning electron microscopy

Future food situation will be strongly dominated by the changes in the population structures, developing economies, changes in diet and associated demand for food. ${ }^{1}$ It is assumed that the growth scenario of the population is predicated to increase by a further 700 million people in the Indogangetic Plains of India (IGP) (about equal to the current population of Europe) in the next 30 years. This will result in a greater demand for food, and it is estimated that the food grain requirement by 2020 in the region will be almost $50 \%$ more than at present. ${ }^{2}$ The IGP is now called as the 'bread basket' for South Asia, which is known to be the most extensive fluvial plains of the world. Rice and wheat are the two major cereal crops of this region, and this region produces about $50 \%$ of the total foodgrains to feed $40 \%$ of country's population. ${ }^{3}$ IGP crops were consistently infested with endemic diseases such as sheath, rots, and wilt diseases caused by phytopathogenic fungi, that is, Rhizoctonia, Macrophomina and Fusarium were difficult to control because of their soil-borne pathogenic nature. They affect countries economy (US\$36 million losses in India), as well as crop yields in tropical and subtropical regions. ${ }^{4,5}$ Pesticides were reported to cause adverse effects on soil ecosystem and also induce resistance in pathogens. ${ }^{6}$ Nowadays biological pesticides are used as a potential tool to replace or augment conventional plant disease management that makes use of synthetic pesticides. ${ }^{7-10}$ Rhizobacteria are beneficial to crops yields via nutrient acquisition, ${ }^{11}$ biocontrol, ${ }^{12,13}$ plant hormone-like production $^{14}$ and induction of systemic resistance. ${ }^{15}$ Bacillus is cosmopolitan in nature contributing $92 \%$ soil microbial library and effective biocontrol agent for various pests such as Macrophomina phaseolina, ${ }^{16,17}$ Rhizoctonia solani ${ }^{18,19}$ and Fusarium udum. ${ }^{20,21}$ Various Bacillus species have been reported for their capacities to protect plants from pathogens and stimulate plant growth since long time. ${ }^{16-19}$ They are used as a suitable biocontrol agent because of their ability to grow rapidly in vivo as well as in vitro condition, colonize and multiply in the rhizosphere, and compete aggressively with other microorganisms. ${ }^{22}$ The estimation of microbial diversity along with study of its ecological habitat is required for understanding its biogeography, community assembly and ecological processes. ${ }^{23}$ Ribosomal genes (16S rRNA gene) sequencing provides sufficient genetic information for bacterial identification, and it has been widely applied to the identification of different Bacillus species. ${ }^{24,25}$ Amplified rDNA restriction analysis (ARDRA) has been useful for the identification and de-duplication of the microbes within a genus as well as at species level. ${ }^{26}$ In the present work, we discussed the population frequency and diversity analysis of Bacillus showing antagonisms against endemic tropical and subtemperate soil-borne phytopathogens (M. phaseolina, R. solani and F. udum), from different regions of IGP, India, as well as analysis of soil macronutrient composition ( $\mathrm{OC}, \mathrm{N}, \mathrm{P}$ and $\mathrm{K}$ ) and molecular characterization of Bacillus isolates through ARDRA analysis followed by identification by $16 \mathrm{~S}$ rRNA gene sequencing of antagonistic Bacillus from IGP regions of India (see Supplementary Information).

The study area covered a total of 55 rhizospheric soil samples (wheat-rice cropping system) from different IGP regions, India, by using random stratified sampling techniques. The selected IGP regions included six states with coordinates such as Uttrakhand $\left(30^{\circ} 19^{\prime} 48^{\prime \prime}-30^{\circ} 33^{\prime} \mathrm{N}, 78^{\circ} 3^{\prime} 36^{\prime \prime}-78^{\circ} 06^{\prime} \mathrm{E}\right)$, Uttar Pradesh $\left(26^{\circ} 51^{\prime} 0^{\prime \prime}{ }_{-}\right.$ $\left.26^{\circ} 85^{\prime} \mathrm{N}, \quad 80^{\circ} 54^{\prime} 36^{\prime \prime}-80^{\circ} 91^{\prime} \mathrm{E}\right)$, Haryana $\left(30^{\circ} 43^{\prime} 48^{\prime \prime}-30^{\circ} 73^{\prime} \mathrm{N}\right.$, $\left.76^{\circ} 46^{\prime} 48^{\prime \prime}-\quad 76^{\circ} 78^{\prime} \mathrm{E}\right)$, Punjab $\left(30^{\circ} 47^{\prime} 24^{\prime \prime}-30^{\circ} 79^{\prime} \mathrm{N}, \quad 76^{\circ} 46^{\prime} 48^{\prime \prime}-\right.$ $\left.76^{\circ} 78^{\prime} \mathrm{E}\right)$, Rajgir (Bihar) $\left(25^{\circ} 1^{\prime} 48^{\prime \prime}-25^{\circ} 03^{\prime} \mathrm{N}, 85^{\circ} 25^{\prime} 12^{\prime \prime}-85^{\circ} 42^{\prime} \mathrm{E}\right)$ and West Bengal states $\left(22^{\circ} 34^{\prime} 0^{\prime \prime}-22^{\circ} 566667^{\prime} \mathrm{N}, 88^{\circ} 22^{\prime} 0^{\prime \prime}\right.$ $88^{\circ} 366667^{\prime} \mathrm{E}$ ) (Figure 1). Sediment samples were collected at 10-12 days intervals from each site in triplicates. Rhizospheric soil monolith of $5 \mathrm{~cm}^{3}$ along with root were randomly removed from the wheat-rice crop field system, aseptically stored in sterile polythene bags, brought to the laboratory and dried at $30^{\circ} \mathrm{C}$ to obtain constant weight. Each composite soil sample was divided into two parts. One part in the field moist condition was used for determination of soil physiochemical parameters, while other part was used for Bacillus isolation. Samples were kept at $4{ }^{\circ} \mathrm{C}$ for further analysis. Soil texture and 


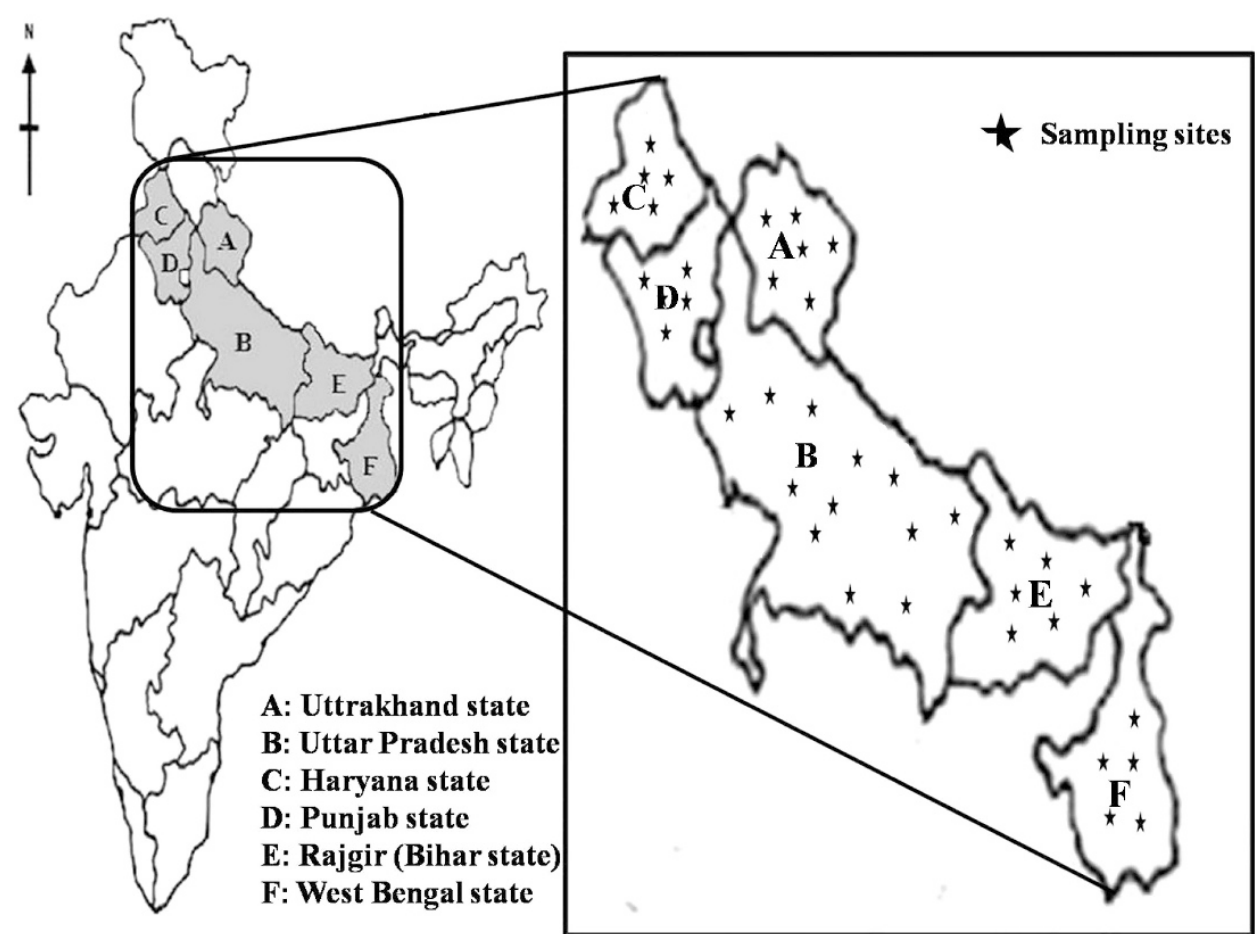

Figure 1 Map showing the sites of soil sample collection ((A) Uttrakhand; (B) Uttar Pradesh; (C) Haryana; (D) Punjab; (E) Rajgir and (F) West Bengal states) from Indo-Gangetic Plain, India.

Table 1 Geographical location, soil physiochemical properties and enumeration of Bacillus isolates from Indogangetic Plains of India

\begin{tabular}{|c|c|c|c|c|c|c|c|c|c|c|}
\hline Location & Coordinates & $\begin{array}{l}\text { CFU } \times 10^{4} \\
\text { per } g \text { of soil }\end{array}$ & Soil texture & $p H$ & $E C$ & $\begin{array}{c}N \\
\left(k g h a^{-1}\right)\end{array}$ & $\begin{array}{c}P \\
\left(k g h a^{-1}\right)\end{array}$ & $\begin{array}{c}\text { K } \\
\left(k g h a^{-1}\right)\end{array}$ & $\begin{array}{c}\text { Total } \\
\text { isolates } \\
\text { picked }\end{array}$ & $\begin{array}{c}\text { Biocontrol } \\
\text { Bacillus } \\
\text { isolates (\%) }\end{array}$ \\
\hline Haridwar & $30^{\circ} 33^{\prime} \mathrm{N} 78^{\circ} 06^{\prime} \mathrm{E}$ & $6-35$ & Loamy-sandy loam & 6.91 & 0.14 & 145.5 & 28.8 & 70.2 & 31 & $17(54.84)$ \\
\hline Dehardun & $29^{\circ} 23^{\prime} \mathrm{N} 79^{\circ} 27^{\prime} \mathrm{E}$ & 3-32 & Loamy-sandy loam & 8.17 & 0.3 & 65.2 & 70.8 & 278.5 & 30 & $15(50.00)$ \\
\hline Nanital & $29^{\circ} 96^{\prime} \mathrm{N} 78^{\circ} 16^{\prime} \mathrm{E}$ & $8-24$ & Loamy-sandy loam & 8.5 & 0.32 & 45.2 & 45.2 & 296.4 & 21 & $14(66.67)$ \\
\hline Almora & $29^{\circ} 59^{\prime} \mathrm{N} 79^{\circ} 65^{\prime} \mathrm{E}$ & $3-15$ & Silt loam & 7.21 & 0.15 & 180.1 & 20.6 & 105.5 & 13 & $9(69.24)$ \\
\hline Punjab & $27^{\circ} 37^{\prime} \mathrm{N} 74^{\circ} 28^{\prime} \mathrm{E}$ & $17-68$ & Clay-silt Ioam & 7.16 & 0.14 & 132.9 & 64.7 & 55.1 & 64 & $18(28.13)$ \\
\hline Lucknow & $26^{\circ} 51^{\prime} \mathrm{N} 80^{\circ} 55^{\prime} \mathrm{E}$ & $13-72$ & Silt clay loam & 9.83 & 1.1 & 70.2 & 46.2 & 395.1 & 60 & $20(33.34)$ \\
\hline Rajgir & $25.03^{\circ} \mathrm{N} 85.42^{\circ} \mathrm{E}$ & $10-46$ & Silt-clay loam & 9.17 & 0.5 & 108.9 & 27.7 & 360.2 & 31 & $20(64.52)$ \\
\hline West Bengal & $22^{\circ} 56^{\prime} \mathrm{N} 77^{\circ} 42^{\prime} \mathrm{E}$ & $16-49$ & Loam-clay loam & 8.32 & 0.33 & 52.7 & 46.4 & 272.6 & 44 & $12(27.28)$ \\
\hline
\end{tabular}

Abbreviations: EC, electrical conductivity; N, nitrogen; K, potassium; OC, organic carbon; P, phosphorous.

Haridwar, Dehardun, Nanital and Almora are located in Uttrakhand state. Lucknow and Rajgir are located in Uttar Pradesh and Bihar states, respectively.

${ }^{a}$ Data in triplicates (positive assay against single/multiple phytopathogenic fungus).

physiochemical properties of soil samples were characterized according to the standard methods. ${ }^{27}$

A total of three hundred thirty-four Bacillus isolates were isolated from different ecoregions of IGP. The population frequencies of Bacillus isolates were fluctuated $\left(3-72 \times 10^{4} \mathrm{~g}\right.$ soil $\left.{ }^{-1}\right)$ such as Punjab belt soils harboured maximum Bacillus population while, Uttrakhand region had least population counts (Table 1). The fluctuation of Bacillus distribution may be due to difference in the physiochemical properties of soil and non uniform distribution of nutrients also. ${ }^{28}$

Screening of Bacillus isolates for the antimicrobial assay against the three test phytopathogenic fungi (M. phaseolina, F. udum and $R$. solani) revealed that a total of $41 \%$ isolates showed antagonism against test phytopathogens, whereas, 19.1, 13.1 and 9.5\% isolates showed inhibition zone towards individually tested pathogens (that is, M. phaseolina, F. udum and R. solani). Moreover, screening based on inhibition zone revealed that a total of $9.2,5.7$ and $3.5 \%$ isolates showed more promising (zone of inhibition $(\mathrm{ZOI})>15 \mathrm{~mm}$ ) towards M. phaseolina, F. udum and R. solani, respectively. Further clustering of isolates were carried out by various combination of phytopathogenic fungal inhibition parameter ( $\mathrm{ZOI}>15 \mathrm{~mm}$ ), that is, $1.4 \%$ Bacillus isolates showed inhibition to all test pathogens (M. phaseolina, F. udum and R. solani), followed by combination of two test fungi, that is, M. phaseolina/F. udum (3.5\%), M. phaseolina/R. solani $(2.8 \%)$ and lastly F. $u d u m / R$. solani $(2.1 \%)$, respectively. The distribution of biocontrol-based Bacillus isolates showed that Uttrakhand regions had maximum biocontrol potential isolates followed by 

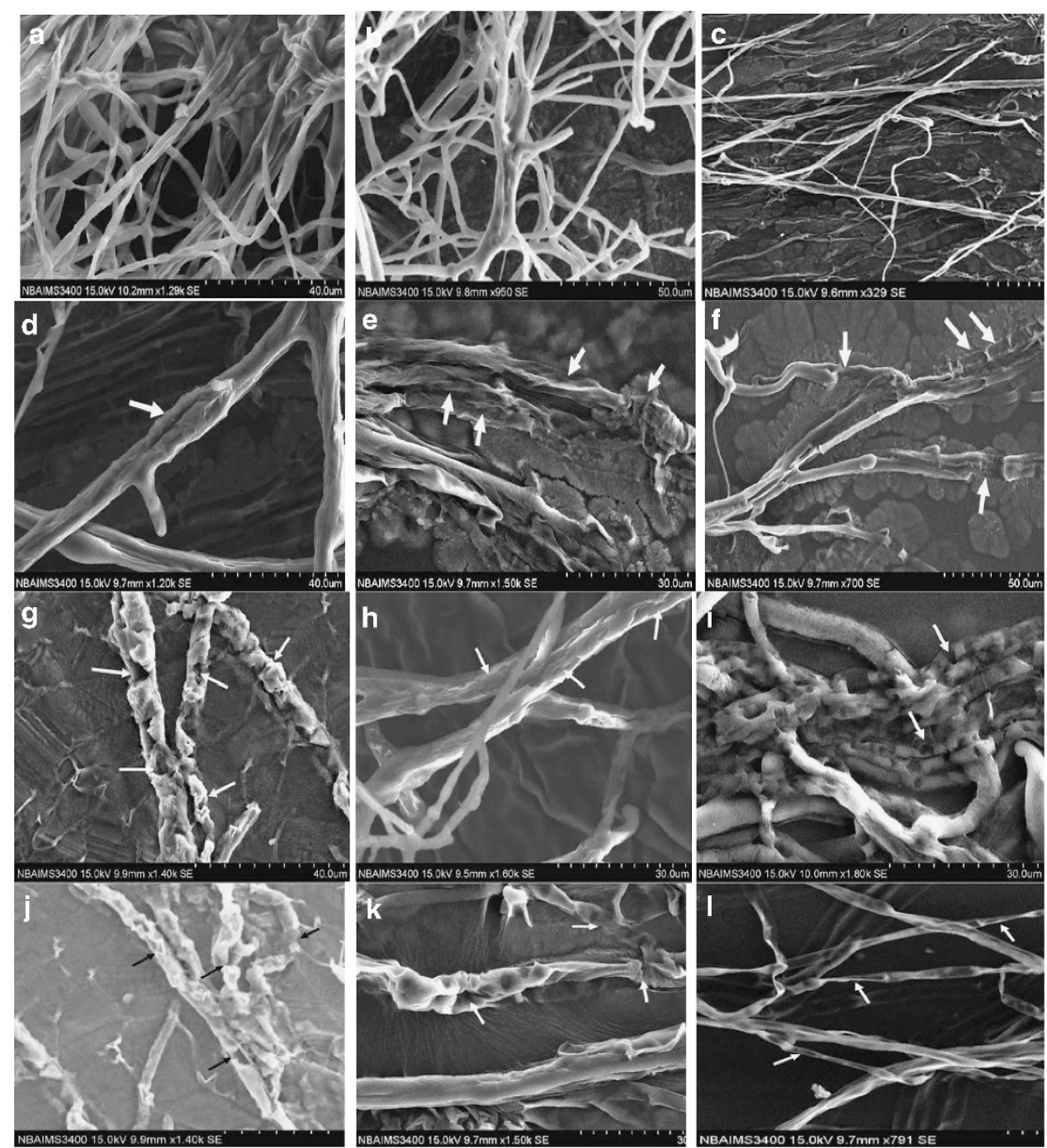

Figure 2 Scanning electron microscopy (SEM) of antagonist Bacillus isolates (TN10) from IGP, India (arrows indicates abnormal growth of fungal mycelia). Healthy mycelia were used as a control ((a) F. udum, (b) M. phaseolina, (c) R. solani); (d, e and f) antagonistic effects of Bacillus isolates on F. udum; (g, h and $\mathbf{i}$ ) antagonistic effects of Bacillus isolates on M. phaseolina; ( $\mathbf{j}, \mathbf{k}$ and $\mathbf{I}$ ) antagonistic effects of Bacillus isolates on $R$. solani.

Rajgiri, Uttar Pradesh, Hariyana, Punjab belt and lastly West Bengal regions. One of the major factors for unequal distribution of biocontrol-based Bacillus may be the excess use of chemical pesticides in Punjab and Haryana region, as compared with other IGP regions, which causes disturbance in the soil physiochemical properties. ${ }^{29}$ Scanning electron microscopic studies between pathogenic fungi and representative isolates $(\mathrm{ZOI}>15 \mathrm{~mm}$ ) by dual plate assay exhibited uneven growth of fungal mycelia as compared with control (healthy mycelia in absence of antagonists) (Figure 2).

Among these, strain TN10 has been found to inhibit the growth of all the three pathogenic fungi, while strains TN3 and NBIGP were effective against both $R$ solani and $M$. phaseolina. Similarly strain TN8 was found to control F. udum and M. phaseolina, while strains NBIGP and NBIGP 24 have been found to produces inhibitory compounds causing damage to the fungal hyphae, as many researchers also reported B. thuringiensis produces sporulation parasporal crystals containing delta-endotoxins. ${ }^{30-32}$ In our study, although the exact mode of action is not clear at present from scanning electron microscopy analysis, it may be concluded that antagonism may be offered by effect of secretion of antimicrobial or hydrolytic compounds from test organisms, which was justified by destruction caused by without any physical contact between antagonists and target pathogen.

Molecular characterization includes DNA fingerprinting (ARDRA analysis), and strain identification is important not only to design suitable biocontrol strategies but also for registration, patenting and recognition of biocontrol bacteria. ARDRA is a useful method for the identification, genotypic diversity and similarity of many prokaryotic microorganisms. ${ }^{33-36}$ In our present study, molecular characterization based on 165 rDNA ARDRA analysis (Figure 3), with a set of three different restriction enzymes viz., AluI, HaeIII and MspI with restriction sites $\mathrm{AG}^{\prime} \mathrm{CT}, \mathrm{GG}^{\prime} \mathrm{CC}$ and $\mathrm{C}^{\prime} \mathrm{CGG}$, respectively, revealed that a total of 140 biocontrol-based Bacillus isolates grouped into 26 representative clusters based on $>50 \%$ similarity level of combined restriction pattern analysis (ARDRA analysis). Representative isolates from each cluster were selected for the identification by sequencing through Sanger's di-deoxy nucleotide sequencing method, and the sequences generated were analyzed by BLASTn followed by the closest 

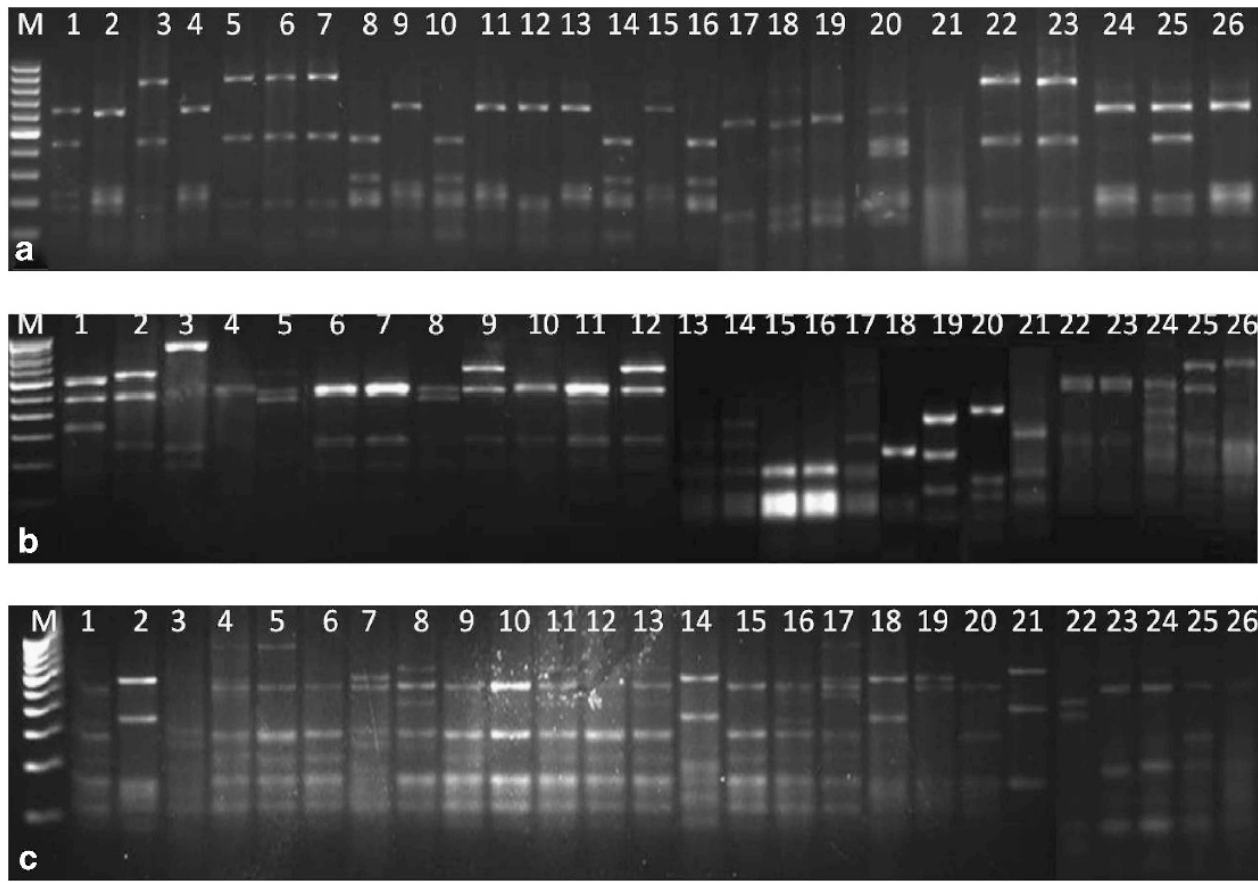

Figure 3 Representative RFLP gel showing PCR product of 16S rDNA digested with different restriction enzymes ((a) Alul; (b) Haelll and (c) Mspl restriction endonuclease enzymes). Lane M contain the 100-bp DNA marker; lane 1, B. licheniformis strain NBIGPBL (accession no. JN004168); lane 2 , B. megaterium strain NBIGP (accession no. JN004170); lane 3, B. thuringiensis strain NBIGP 24 (accession no. JN004169); lane 4, B. fusiformis strain TN1 (accession no. JQ415974); lane 5, B. humi strain TN2 (accession no. JQ415975); lane 6, B. casamancensis strain TN3 (accession no. JQ415976), lane 7, Pontibacillus sp. strain TN4 (accession no. JQ415977); lane 8, Kurthia zopfii strain TN5 (accession no. JQ415978); lane 9, B. cereus strain TN7 (accession no. JQ415980); lane 10, B. arbutinivorans strain TN8 (accession no. JQ415981); lane 11, B. clausii strain TN9 (accession no. JQ415996); lane 12, Brevibacillus parabrevis strain TN10 (accession no. JQ415982); 13, Brevibacillus brevis strain TN13 (accession no. JQ415985); lane 14, B. subtilis strain TN14 (accession no. JQ415986); lane 15, B. drentensis strain TN15 (accession no. JQ415987); lane 16, Lysinibacillus sphaericus strain TN16 (accession no. JQ415988); lane 17, B. niacin strain TN17 (accession no. JQ415989); lane 18, B. fumarioli strain TN18 (accession no. JQ415990); lane 19, B. oleronius strain TN19 (accession no. JQ415991); lane 20, B. thermoamylovorans strain TN20 (accession no. JQ415992); lane 21, B. farraginis strain TN6 (accession no. JQ415979); lane 22, B. mycoides strain TN12 (accession no. JQ415984); lane 23, Paenibacillus polymyxa strain TN21 (accession no. JQ415993); lane 24, B. soli strain TN22 (accession no. JQ415994); lane 25, Paucisalibacillus globulus strain TN23 (accession no. JQ415995); and lane 26, B. koreensis strain TN11 (accession no. JQ415983).

Table 2 Closest BLASTN matches for the full 16S rDNA sequences and their percentage similarity with the closest biocontrol-based Bacillus strains

\begin{tabular}{|c|c|c|c|c|}
\hline $\begin{array}{l}\text { S. } \\
\text { No. }\end{array}$ & $\begin{array}{l}\text { Strain } \\
\text { codes }\end{array}$ & Most similar type strain (\%similarity/accession no.) & Most similar species (\%similarity/accession no.) & $\begin{array}{c}\text { Accession } \\
\text { number }\end{array}$ \\
\hline 1 & NBIGP BL & Bacillus aerius strain 24K (99\%/NR_042338.1) & Bacillus licheniformis strain ISA9 (99\%/HQ189753.1) & JN004168 \\
\hline 2 & NBIGP & Bacillus megaterium strain IAM 13418 (99\%/NR_043401.1) & Bacillus megaterium strain WN611 (99\%/DQ275184.1) & JN004170 \\
\hline 3 & NBIGP 24 & Bacillus thuringiensis strain IAM 12077 (99\%/NR_043403.1) & Bacillus thuringiensis strain KVP109 (98\%/JX290089.1) & JN004169 \\
\hline 4 & TN1 & Lysinibacillus boronitolerans strain 10a (98\%/NR_041276.1) & Bacillus fusiformis strain RSNPB4 (99\%/HM588144.1) & JQ415974 \\
\hline 5 & TN2 & Bacillus humi strain LMG 22167 (97\%/NR_025626.1) & Bacillus humi strain NBIGP 23 (100\%/JF304284.1) & JQ415975 \\
\hline 6 & TN3 & Bacillus shackletonii strain LMG 18435 (97\%/NR_025373.1) & Bacillus casamancensis (100\%/AF519462.1) & JQ415976 \\
\hline 7 & TN4 & Pontibacillus marinus strain BH030004 (95\%/NR_043011.1) & Pontibacillus sp. strain BH85057-2 (100\%/FJ897778.1) & JQ415977 \\
\hline 8 & TN5 & Bacillus fortis strain R-6514 (95\%/NR_042905.1) & Kurthia zopfii strain NBIGP 4 (99\%/JF304286.1) & JQ415978 \\
\hline 9 & TN6 & Bacillus farraginis strain R-6540 (99\%/NR_025785.1) & Bacillus farraginis strain R-6915 (100\%/AY443037.1) & JQ415979 \\
\hline 10 & TN7 & Bacillus thuringiensis strain IAM 12077 (98\%/NR_043403.1) & Bacillus cereus strain NBIGP 14 (99\%/JF304293.1) & JQ415980 \\
\hline 11 & TN8 & Bacillus drentensis strain IDA1967 (98\%/NR_029002.1) & Bacillus arbutinivorans strain NBIGP 11 (100\%/JF304294.1) & JQ415981 \\
\hline 12 & TN9 & Bacillus clausii strain DSM8716 (99\%/NR_026140.1) & Bacillus clausii strain NBIGP 3 (100\%/JF304285.1) & JQ415996 \\
\hline 13 & TN10 & Brevibacillus parabrevis strain IFO 12334 (97\%/NR_040981.1) & Brevibacillus parabrevis strain NBIGP 2 (100\%/JF304283.1) & JQ415982 \\
\hline 14 & TN11 & Bacillus korlensis strain ZLC-26 (97\%/NR_044538.1) & Bacillus koreensis (98\%/FJ889614.1) & JQ415983 \\
\hline 15 & TN12 & Bacillus thuringiensis strain IAM 12077 (97\%/NR_043403.1) & Bacillus mycoides strain 820 (98\%/FJ544336.1) & JQ415984 \\
\hline 16 & TN13 & Bacillus thuringiensis strain IAM 12077 (99\%/NR_043403.1) & Brevibacillus brevis strain NBIGP 7 (100\%/JF304289.1) & JQ415985 \\
\hline 17 & TN14 & $\begin{array}{l}\text { Bacillus subtilis subsp. subtilis strain DSM10 (99\%/ } \\
\text { NR_027552.1) }\end{array}$ & Bacillus subtilis strain ZMO6 (99\%/JF932296.1) & JQ415986 \\
\hline 18 & TN15 & Bacillus drentensis strain IDA1967 (98\%/NR_029002.1) & Bacillus drentensis strain YNB2 (99\%/JN712311.1) & JQ415987 \\
\hline
\end{tabular}


Table 2 (Continued)

\begin{tabular}{|c|c|c|c|c|}
\hline $\begin{array}{l}\text { S. } \\
\text { No. }\end{array}$ & $\begin{array}{l}\text { Strain } \\
\text { codes }\end{array}$ & Most similar type strain (\%similarity/accession no.) & Most similar species (\%similarity/accession no.) & $\begin{array}{c}\text { Accession } \\
\text { number }\end{array}$ \\
\hline 19 & TN16 & Lysinibacillus sphaericus strain DSM28 (99\%/NR_042073.1) & $\begin{array}{l}\text { Lysinibacillus sphaericus strain VCRC B543 (99\%/ } \\
\text { JN377786.1) }\end{array}$ & JQ415988 \\
\hline 20 & TN17 & Bacillus drentensis strain IDA1967 (98\%/NR_029002.1) & Bacillus niacini strain NBIGP 8 (100\%/JF304290.1) & JQ415989 \\
\hline 21 & TN18 & Bacillus fumarioli strain LMG17489 (99\%/NR_025370.1) & Bacillus fumarioli strain R-14705 (99\%/AJ581126.1) & JQ415990 \\
\hline 22 & TN19 & Bacillus oleronius strain ATCC 700005 (99\%/NR_043325.1) & Bacillus oleronius strain 11 (99\%/EU430987.1) & JQ415991 \\
\hline 23 & TN20 & Bacillus thermoamylovorans strain DKP (99\%/NR_029151.1) & $\begin{array}{l}\text { Bacillus thermoamylovorans strain BHK180-4 (99\%/ } \\
\text { AB360824.1) }\end{array}$ & JQ415992 \\
\hline 24 & TN21 & Paenibacillus jamilae strain CECT 5266 (98\%/NR_042009.1) & Paenibacillus polymyxa strain M1 (99\%/HE577054.1) & JQ415993 \\
\hline 25 & TN22 & Bacillus soli strain R-16300 (99\%/NR_025591.1) & Bacillus soli strain LMG 21839 (99\%/AJ542514.1) & JQ415994 \\
\hline 26 & TN23 & $\begin{array}{l}\text { Ornithinibacillus californiensis strain MB-9 (98\%/ } \\
\text { NR_041820.1) }\end{array}$ & Paucisalibacillus globulus strain 5 (100\%/EU430986.1) & JQ415995 \\
\hline
\end{tabular}

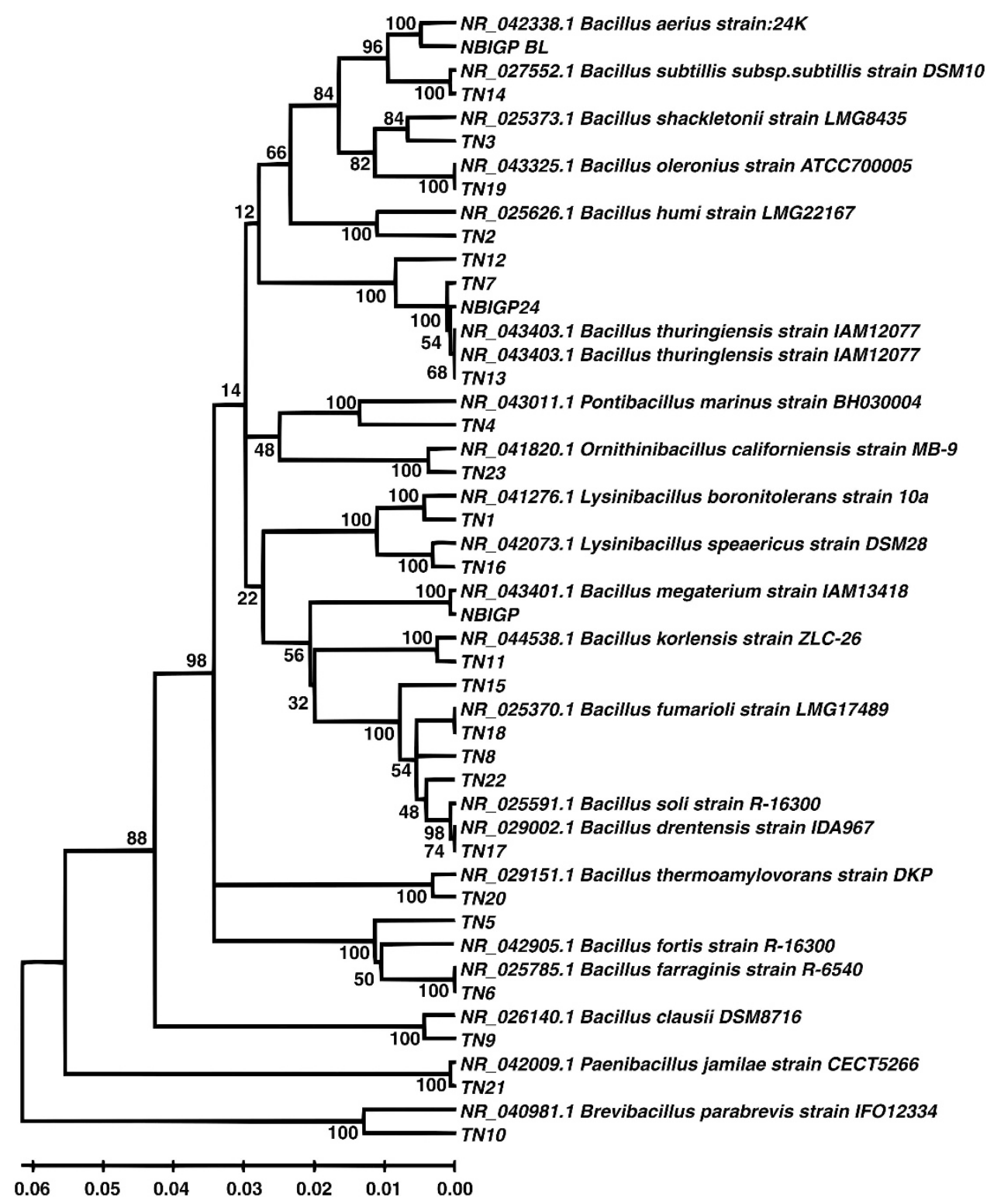

Figure 4 Phylogenetic tree of 16S rRNA sequences from selected isolates by unweighted pair group method of arithmetic mean method. The sequence data for several closely related Bacillus isolates were recovered from genebank and included in the tree. The accession numbers and their sequences recovered from genbank are as follows: the boot strap values from 5000 pseudoreplications are shown at each of the branch points on the tree. Bar indicates \% similarity. 
taxonomic affiliation of the sequences matched from public database (NCBI, Genbank) (Table 2), and results revealed that strains TN4, TN5, TN2, TN11 and TN3 are distantly related to type strains of previous known species with 95, 95, 97, 97, 97\% of similarity, respectively. Further phylogenetic analysis was carried out by construction of dendogram of all the representative isolates and compared with the submitted $16 \mathrm{~S}$ rRNA sequences in public database (Figure 4). This phylogenetic tree revealed that the biocontrol potential Bacillus isolates were phylogenetically diverse in the genus Bacillus and related genera, which belonged to the two families.

In conclusion, the results showed an evidence of high diversity of Bacillus strains in rice-wheat rhizosphere ecosystem at IGP. A total of 26 representative Bacillus isolates showed antagonism against M. phaseolina, F. udum and R. solani and were phylogenetic diverse in nature. The diversity analysis of Bacillus with respect to antagonistic behaviour had enriched our knowledge in most fertile regions of India. Our study further increases the information of Bacillus species showing biocontrol activity (evident by scanning electron microscopy), which was available for developing suitable biocontrol strategies as well as enable us for the recognition of biocontrol bacteria from rhizospheric soil of rice-wheat ecosystem.

\section{ACKNOWLEDGEMENTS}

The study was supported by the grant from Indian Council of Agricultural Research (ICAR), New Delhi, India, under the Application of Microbes in Agriculture and Applied sectors Network Project. We acknowledge ICAR for their support.

1 Rabbinge, R. In The Role of Asia in World of Food Security. (eds, Bindraban, P. S., Van K. H., Kuyvenhoven, A., Rabbinge, R. \& Uithol, P. W. J.) 153-157 (AB-DLO \& PE, Wageningen, The Netherlands, 1999).

2 Paroda, R. S. \& Kumar, P. Food production and demand in South Asia. Agri. Econ. Res. Rev. 13, 1-24 (2000)

3 Swaminathan, M. S. Science and Integrated Rural Development (Concept Publishing, New Delhi, India, 1982).

4 Siddiqui, Z. A. \& Mahmood, I. Effects of Heterodera cajani, Meloidogyne incognita and Fusarium udum on the wilt disease complex of pigeon pea. Ind. J. Nematol. 26 , 102-104 (1996).

5 Siddiqui, Z. A. \& Mahmood, I. Effects of inoculations of Heteroder cajani, Meloidogyne incognita and Fusarium udum and Bradyrhizobium japonicum on the wilt disease complex of pigeon pea. Ind. Phytopathol. 52, 66-70 (1999a).

6 Cohen, Y. \& Leavy, Y. Joint action of fungicides in mixtures: theory and practice. Phytoparasitica 18, 159-169 (1990).

7 Mukhopadhyay, A. N. Biological control of soil-borne plant pathogens by Trichoderma spp. Ind. J. Mycol. Pt. Pathol. 17, 1-9 (1987).

8 Pusey, P. L. Use of Bacillus subtilis and related organism as biofungicides. Petrichem Sci. 27, 133-134 (1989).

9 Smith, V. L., Wilcox, W. F. \& Harman, G. E. Potential for biological control of Phytopthora root and crown rot of apple by Trichoderma and Gliocladium spp. Phytopathology 80, 880-885 (1990).

10 Bashar, M. A. \& Rai, B. Antagonistic potential of root region microflora of chickpea against Fusarium oxysporum f.sp. ciceri. Bangladesh J. Bot. 23, 13-19 (1994).

11 Dobbelaere, S., Vanderleyden, J. \& Okon, Y. Plant growth-promoting effects of diazotrophs in the rhizosphere. Crit. Rev. Pt. Sci. 22, 107-149 (2003).
12 Walsh, U. F., Morrissey, J. P. \& O' Gara, F. Pseudomonas for biocontrol of phytopathogens: from functional genomics to commercial exploitation. Curr. Opin. Biotechnol. 12, 289-295 (2001)

13 Woeng, C. A. T. F. C., Thomas-Oates, J. E., Lugtenberg, B. J. J. \& Bloemberg, G. V. Introduction of the phzH gene of Pseudomonas chlororaphis PCL1391 extends the range of biocontrol ability of phenazine-1-carboxylic acid-producing Pseudomonas spp. strains. Mol. Plant-Microbe Interact. 14, 1006-1015 (2001).

14 Steenhoudt, O. \& Vanderleyden, J. Azospirillum, a free-living nitrogen-fixing bacterium closely associated with grasses: genetic, biochemical and ecological aspects. FEMS Microbiol. Rev. 24, 487-506 (2000).

15 van Loon, L. C., Bakker, P. A. H. M. \& Pieterse, C. M. J. Systemic resistance induced by rhizosphere bacteria. Ann. Rev. Phytopathol. 36, 453-483 (1998).

16 Alippi, J. \& Monaco, C. In vitro antagonism against Bacillus species and Sclerotium rolfsii, Fusarim solani. Rev. Fac. Agron. (B. Aires) 70, 91-95 (1994).

17 Sandra, G. A. et al. Identification and biological characterization of isolates with activity inhibitive against Macrophomina phaseolina (Tassi) Goid. Chilean J. Agri. Res 69, 526-533 (2009).

18 Knaak, N., Rohr, A. A. \& Fiuza, L. M. In vitro effect of Bacillus thuringiensis strains and cry proteins in phytopathogenic fungi of paddy rice-field. Braz. J. Microbiol. $\mathbf{3 8}$ 526-530 (2007)

19 Rajendran, L. \& Samiyappan, R. Endophytic Bacillus species confer increased resistance in cotton against damping off disease caused by Rhizoctonia solani. J. Plant Pathol. 7, 1-12 (2008).

20 Singh, R., Singh, B. K., Upadhyay, R. S., Bharat, R. \& Youn, S. L. Biological control of Fusarium wilt disease of pigeon pea. J. Plant Pathol. 18, 279-283 (2002).

21 Siddiqui, Z. A. \& Shakeel, U. Screening of Bacillus isolates for potential biocontrol of the wilt disease complex of pigeon pea (Cajanus cajan) under greenhouse and smallscale field conditions. J. Plant Pathol. 89, 179-183 (2007).

22 Weller, D. M., Raaijmakers, J. M., McSpadden, G. B. B. \& Thomashow, L. S. Microbia populations responsible for specific soil suppressiveness to plant pathogens. Ann. Rev. Phytopathol. 40, 309-348 (2002).

23 Curtis, T. P., Sloan, W. T. \& Scannell, J. W. Estimating prokaryotic diversity and its limits. Proc. Natl Acad. Sci. USA 99, 786-790 (2002).

24 Fox, G. E., Wisotzkey, J. D. \& Jurtshunk, P. Jr. How close is close: 16S rRNA sequence identity may not be sufficient to guarantee species identity. Int. J. Syst. Bacteriol. 42 166-170 (1992)

25 Vardhan, S., Kaushik, R., Saxena, A. K. \& Arora, D. K. Restriction analysis and partial sequencing of the 16S rRNA gene as index for rapid identification of Bacillus species. Anton. Van Leeuwen. 99, 283-296 (2011).

26 Wahyudi, A. T., Prasojo, B. J. \& Mubarik, N. R. Diversity of antifungal compounds producing Bacillus spp. Isolated from Rhizosphere of soybean plant based on ARDRA and 16S rRNA. Hayati J. Biosci. 17, 145-150 (2010).

27 American Public Health Association (APHA) Standard Methods for the Examination of Water and Wastewater. 15th edn (American Public Health Association (APHA), Washington, DC, USA, (1980)

28 Wenzhofer, F., Holby, O. \& Kohls, O. Deep penetrating benthic oxygen profiles measured in situ by oxygen optodes. Deep Sea Res. Partl Oceanogr. Res. Pap. 48 $1741-1755$ (2001).

29 Sharma, S. K., Subba Rao, A. V. M. \& Murari, K. Atlas of rice-wheat cropping system in Indo-Gangetic Plains of India. Modipuram, India. Bulletin No. 2004-I, PDCSR (ICAR), pp. 110 (2004).

30 Glare, T. R. \& O'Callaghan, M. Bacillus thuringiensis: Biology, Ecology and Safety (John Wiley and Sons Ltd., Chichester, UK, 2000).

31 Hofte, H. \& Whiteley, H. R. Insecticidal proteins of Bacillus thuringiensis. Microbiol. Rev. 53, 242-255 (1989).

32 Lereclus, D., Delecluse, A. \& Lecadet, M. InDiversity of Bacillus thuringiensis toxins and genes. (eds, Entwistle, P. F., Cory, J. S., Bailey, M. J. \& Higgs, S.) 37-69 (John Wiley \& Sons Ltd., New York City, 1993).

33 Yang, J. H. et al. Diversity analysis of antagonists from rice-associated bacteria and their application in biocontrol of rice diseases. J. Appl. Microbiol. 104, 91-104 (2007)

34 Sasaki, E., Osawa, R., Nishitani, Y. \& Whiley, R. A. ARDRA and RAPD analysis of human and animal isolates of Streptococcus gallolyticus. J. Vet. Med. Sci. 66 , 1467-1470 (2004)

35 Moreira, J. L. et al. Identification to the species level of Lactobacillus isolated in probiotic prospecting studies of human, animal, or food origin by 16S-23S rRNA restriction analysis profiling. BMC Microbiol. 23, 5-15 (2005)

36 Pooeshafie, M., Vahdani, P. \& Popoff, M. Genotyping Clostridium botulinum toxinotype A isolates from patients using amplified rDNA restriction analysis. J. Med. Microbiol. 54, 936 (2005).

Supplementary Information accompanies the paper on The Journal of Antibiotics website (http://www.nature.com/ja) 